\title{
What happened to women working in the hospitality industry when COVID-19 struck?
}

\section{Lin Chen and Shelagh Mooney}

Lin Chen is a postgraduate researcher at AUT. Her interests lie in understanding individuals' experiences and relationships at work, as well as the changeable circumstances experienced by different social groups in specific settings.

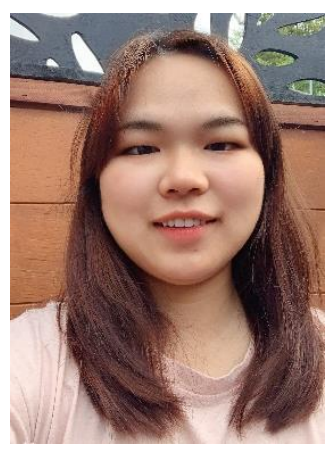

Dr Shelagh Mooney is Associate Professor of Hospitality \& Tourism at AUT. Her research focuses on issues of gender equity with a focus on developing ethical leaders for a sustainable tourism workforce, which enjoys decent work and fair rewards.

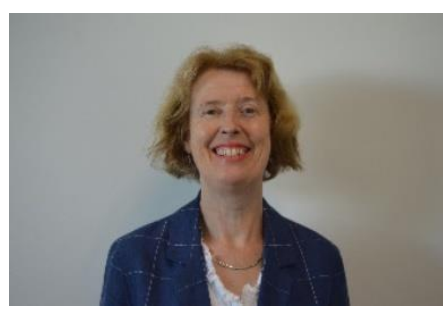

This original unpublished study explored the impact of COVID-19 on women working in the hospitality industry. The industry is a significant employer and its workforce has been, and continues to be, adversely affected by the COVID19 crisis. ${ }^{1}$ Worldwide, much of the hospitality workforce is female-dominated ${ }^{2}$ and, globally, women were most affected by the pandemic and suffered more job losses than men in the unpredictable and changing conditions. ${ }^{3}$ Therefore, exploring women's employment in the hospitality industry during the crisis is an important issue to investigate.

Before COVID-19, women employed in hospitality had poorer quality jobs, with lower pay and fewer career opportunities than men. ${ }^{4}$ From a critical perspective, women's weaker employment position appears related to three aspects of hospitality organisations. Firstly, the glass ceiling associated with the absence of a gender equality lens in organisations forms invisible barriers that hinder women's careers. ${ }^{5}$ Secondly, women's underrepresentation in executive management teams leads to their lack of agency in overcoming long-standing gender injustices. ${ }^{6}$ Thirdly, negative gender-based stereotypes related to women's presumed domestic skills and the feminised nature of many jobs, for example, housekeeping, retain women at the industry's lower levels; women working in the hospitality industry are stereotyped as prioritising family and household responsibilities. 6, 7

An interpretivist approach guided the collection of secondary data from three mass media news sources with a New Zealand focus: Radio New Zealand, the New Zealand Herald, and the Guardian. A convenience sampling strategy was used to collect 63 relevant news reports, from $23^{\text {rd }}$ January to $23^{\text {rd }}$ September 2020, by selecting keywords such as 'women in COVID-19' and 'hospitality work', from the targeted news platforms. Data analysis according to Braun and Clark's (2013) thematic analytical method ${ }^{8}$ revealed four main themes related to COVID-19's impact on the hospitality industry, and women's employment. The routine social and physical interactions between people ceased abruptly, or were disrupted by COVID-19, leading to changes in hospitality operations and to the workforce. Women's hospitality employment and careers also changed significantly. Whether they were forced to, or 'voluntarily' stayed home, women suddenly assumed the role of primary caregiver, along with domestic responsibilities and extra time-consuming commitments, such as children's schooling. Consequently, women lost their jobs and were unable to 
avail of any new opportunities posed by the COVID-19 crisis.

The key finding of this study is that the historic gender-based stereotyping of women employees (that they will prioritise family responsibilities) became the new reality for many women during the COVID-19 crisis. Following lockdown situations, while women remained at home, men tended to go back to work. Therefore, as women already held a disadvantaged employment position before COVID-19, this novel crisis only magnified existing problems. The study showed the benefit of using mass media as data sources in hospitality research as they gave 'real time' snapshots of the negative effects of the Covid-19 crisis for women workers in the hospitality industry, in New Zealand and globally. The crucial message is that finally, gender equality must become an important priority for hospitality organisations post-pandemic.

\section{Corresponding author}

Lin Chen may be contacted at: tff7821@autuni.ac.nz.

\section{References}

(1) Jones, P., Comfort, D. The COVID-19 crisis and sustainability in the hospitality industry. International Journal of Contemporary Hospitality Management, 2020, 32(10), 3037-3050. https://doi-org/10.1108/IJCHM-04-2020-0357.

(2) Baum, T., Mooney, S., Robinson, R., Solnet, D. Covid-19's impact on the hospitality workforce - new crisis or amplification of the norm? International Journal of Contemporary Hospitality Management, 2020, 32(9), 2813-2829. https://doi.org/10.1108/IJCHM-04-2020-03

(3) Wenham, C., Smith, J., Davies, S. E., Feng, H., Grépin, K. A., Harman, S., ... \& Morgan, R. (2020). Women are most affected by pandemics-lessons from past outbreaks. https://www.nature.com/articles/d41586-020-02006-Z

(4) Santero-Sanchez, R., Segovia-Pérez, M., Castro-Nuñez, B., Figueroa-Domecq, C., \& TalónBallestero, P. (2015). Gender differences in the hospitality industry: A job quality index. Tourism Management, 51, 234-246.

(5) Simpson, R. \& Kumra, S. (2016). The Teflon effect: when the glass slipper meets merit. Gender in Management: An International Journal, 31(8), 562-576. https://doi.org/10.1108/GM-12$\underline{2014-0111}$

(6) Mooney, S., Ryan, I., \& Harris, C. (2017). The intersections of gender with age and ethnicity in hotel careers: Still the same old privileges? Gender, Work \& Organization, 24(4), 360-375. https://doi-org/10.1111/gwao.12169

(7) Costa, C., Bakas, F. E., Breda, Z., Durão, M., Carvalho, I., Caçador, S. (2017). Gender, flexibility and the 'ideal tourism worker'. Annals of Tourism Research, 2017, 64, 64-75. https://doi.org/10.1016/j.annals.2017.03.002.

(8) Clarke, V., Braun, V. Teaching thematic analysis: Overcoming challenges and developing strategies for effective learning. The Psychologist, 2013, 26(2), 120-123. https://doi.org/10.1080/17439760.2016.1262613 